\title{
Structure and distribution of Hydrachnidia (Parasitengona-Acari) in the sub-basin of the Grande River (Superior Basin of Quinto River. San Luis-Argentina)
}

\author{
Estrutura e distribuição dos Hidracáridos (Parasitengona-Acari) na Subcuenca do \\ Rio Grande (Conta Superior do Rio Quinto. San Luis-Argentina)
}

Carlos Raul Quiroga ${ }^{1}$, Adriana Vallania ${ }^{1}$ and Beatriz Elena Rosso de Ferradás ${ }^{2}$
'Área de Zoología, Facultad de Química, Bioquímica y Farmacia, Universidad Nacional de San Luis, Chacabuco, 917, CP 5700, San Luis, Argentina
e-mail: cquiroga@unsl.edu.ar,vallania@unsl.edu.ar
${ }^{2}$ CONICET, Cátedra de Diversidad Animal, Facultad de Ciencias Exactas, Físicas y Naturales, Universidad Nacional de Córdoba, Av. Vélez Sarsfield, 299, CP 5000, Córdoba, Argentina e-mail: brosso@com.uncor.edu

\begin{abstract}
Aim: The purpose of this work was to determine genera diversity, structural attributes and distribution of the Hydrachnidia assemblages and their possible influences with certain abiotic parameters along the sub-basin of the Grande River, a $6^{\text {th }}$ order stream in the province of San Luis; Methods: four sampling sites (C1, E1, E2 and E3) were established in two different hydrological periods: high waters (HW) and low waters (LW). Twenty-four samples were obtained using Surber sampler, and the hydraulic, physical and chemical characterization of the sampling sites was carried out. Density (ind. $\mathrm{m}^{-2}$ ), genus richness, Shannon-Wiener diversity index and Kownacki's dominance index were calculated; Results: sixteen Hydrachnidia genera were observed. No significant differences were found between the abiotic parameters of each site. A positive correlation of Sperchon, Torrenticola and Neoatractides was observed in relation to flow and current velocity whereas Hygrobates showed a negative correlation. No significant differences were observed in Hydrachnidia abundances among the sites in HW and LW and between the pairs of each site in HW and LW. The genera with the highest densities were Hygrobates, Limnesia and Atractides, of which the first two were widely distributed. The rest only appeared sporadically. According to Kownacki's index Hygrobates and Limnesia were "dominant", Atractides were "subdominant" and the rest were "non dominant"; Conclusions: The found genera were distanced systematically and philogenetically. However, the specimens belonging to these genera exhibited very similar morphological characteristics, which were adaptations to rheophilous habitats. The representativity of Hygrobates and Limnesia might be due to the great abundance of their hosts and preys in the sub-basin. The decrease in the densities and the changes in the Hydrachnidia composition in E3 (post-dam site) might be explained by the biotic interactions previously mentioned.
\end{abstract}

Keywords: rheophilous Hydrachnidia, generic richness, spatio-temporal distribution, hydraulic parameters.

Resumo: Objetivo: O objetivo deste trabalho foi conhecer a diversidade de gêneros, os atributos estruturais e a distribuiçáo da comunidade de hidracáridos, como assim também a sua possível influência sobre certos parâmetros abióticos, na sub-bacia do Rio Grande, San Luis; Métodos: estabeleceram-se quatro locais de amostragem (C1, E1, E2 e E3) em dois períodos hidrológicos: águas altas (AA) e águas baixas (AB). Obtiverem-se 24 amostras com rede Surber e se realizou a caracterização hidráulica, física e química dos locais de amostragem. Calculou-se a densidade $\left(\right.$ ind. $\mathrm{m}^{-2}$ ), a riqueza genérica e o índice da diversidade de Shannon-Wiener; Resultados: registraram-se 16 gêneros de hidracáridos. Não houve diferenças significativas entre cada local com relação aos parâmetros abióticos. Observou-se uma correlação positiva entre Sperchon, Torrentícola e Neoatractides com relação ao fluxo e à corrente, ao passo que Hygrobates mostrou uma correlação negativa. Não houve diferenças significativas nas abundâncias absolutas de hidracáridos entre os locais em $\mathrm{AA}$ e $\mathrm{AB}$ nem entre os pares de cada local em $\mathrm{AA}$ e em $\mathrm{AB}$. Os gêneros que apresentaram as maiores densidades foram Hygrobates, Limnesia e Atractides, dos quais os dois primeiros apresentaram-se mais amplamente distribuídos. Os demais gêneros somente apareceram esporádicamente. De acordo com o índice de Kownacki, 
Hygrobates e Limnesia foram "dominantes", Atractides foi "subdominante", e o resto foi "não-dominante"; Conclusóes: os gêneros encontrados apresentaram-se distantes tanto filogenéticamente quanto sistemáticamente. Porém, os espécimes desses gêneros foram similares morfológicamente, apresentando características adaptativas à habitats teófilos. A representatividade de Hygrobates e Limnesia poderia se dever à grande abundância de seus hospedeiros e presas na sub-bacia. A diminuição na densidade e as mudanças na composição de hidracáridos em E3 (local após barragem) poderiam ser explicadas pelas interaçóes abióticas antes mencionadas.

Palavras-chave: hidracáridos reófilos, riqueza genérica, distribuição espaço-temporal, parâmetros hidráulicos.

\section{Introduction}

Acari, including aquatic and terrestrial species, are nowadays the most diverse and abundant of all arachnids and comprise about 60 families. Hydrachnidia, the aquatic acari of the Order Prostigmata, Sub-order Parasitengona (Evans, 1992), include 5,000 species of the 7,000 described species.

Because of their adaptive radiation from different terrestrial lineages, Hydrachnidia constitute a complex and heterogeneous group with a great morphological diversity. They also exhibit the possibility to occupy different aquatic environments which have resulted in the formation of homoplasy, which leads to difficulties in the taxonomic determination, mainly when the relations between the groups are not clear. As a consequence, Hydrachnidia have been little studied despite their importance in the aquatic ecosystems (Rosso de Ferradás and Fernández, 2001).

Another particular characteristic of Hydrachnidia is their complex biological cycle; they present development stages with larvae very different from adults and nymph stages not only in their morphology but also in their habitats. Those larvae are parasites of certain insect taxa whereas nymphs and adults are predators of microcrustaceans and different insect taxa (Fernández and Rosso de Ferradás, 2008).

In the Neotropical region, important studies of the Hydrachnidia fauna have been carried out. However, due to the great environmental heterogeneity and the existent microhabitats there are still large unexplored regions in South America. According to some acarologists, only about $25 \%$ of the South American species are well known (Rosso de Ferradás and Fernández, 2005, 2009). In Argentina, the most relevant works on acari have been carried out by Rosso de Ferradás since 1973. In the altiplanes of the NW of Argentina, Fernández has widely contributed to Hydrachnidia knowledge from the taxonomical point of view as well as from the ecological point of view. The central-west region of Argentina (which includes the provinces of San Luis, Mendoza and San Juan) is particularly interesting in relation to Hydrachnidia since there are no previous studies, and the Hydrachnidia fauna is almost unknown. The aim of this work is to know the diversity, taxonomic richness and numerical abundance of the different Hydrachnidia taxa and to analyze their spatial and temporal distribution in the study area. Possible influences of these taxa according to some abiotic parameters will also be established.

\section{Materials and Methods}

The study was carried out in the sub-basin of the Grande River, which belongs to the superior basin of the Quinto River, located in the north central region of the province of San Luis. In this basin, the water is drained towards the south east in the eastern side of the hills of San Luis. These hills constitute the most important mountain range in the province, and they are part of the central group of the Sierras Pampeanas system. The sub-basin of the Grande River has an area of $291.3 \mathrm{~km}^{2}$, a maximum height of 2,160 m, a minimum height of $1,070 \mathrm{~m}$ a.s.l. and it is a $6^{\text {th }}$ order stream (Strahler, 1957).

Four sampling sites were established: C1, E1, $\mathrm{E} 2$, selected because of their increasing flows, were characterized for being of low order, accessible and pristine; and E3, located after the dam, was selected for being an anthropized environment (Figure 1). C1 was established in an effluent of the Grande River located in its origins and with the lowest flow. The section between E2 and the Esteban Agüero dam was not accessible since there were no roads and the river was enclosed by steep hills.

The samplings were carried out in high waters (HW) (March 1998) and low waters (LW) (October 1998). Figure 2 shows the hydrograph with the monthly precipitations and flows of the pre-dam 
sample sites during a complete year. Because of the heavy rainfalls in February and the consequent removal of the substrates, which usually causes the detachment and drifting of the macroinvertebrates, it was necessary to wait until the hydraulic parameters of the river were stable. This permitted to find greater diversity of Hydrachnidia in summer.

The following geographical attributes were determined in each site: elevation, longitude from the source and stream order (Table 1).

To estimate the river hydraulic parameters, two transversal transects were determined in every site and in every sampling period to measure width and depth every $30 \mathrm{~cm}$. Surface current velocity was measured three times in $5 \mathrm{~m}$ using floater (an orange), and measures were averaged. The flows were calculated using the area obtained and the current velocity. Temperature (accuracy $\pm 0.5^{\circ} \mathrm{C}$ ), conductivity (accuracy $\pm 1 \%$ ), $\mathrm{pH}$ (accuracy \pm $0.01 \mathrm{pH}$ ) and turbidity (FTU) were measured in situ using portable sensors. Water samples for the chemical analyses were collected in polythene bottles and taken to the lab where alkalinity and hardness were determined. The design for field sampling was stratified at random. Samples of Hydrachnidia were obtained using Surber sampler with an area of $0.09 \mathrm{~m}^{2}$ and $300 \mu \mathrm{m}$ net mesh size. Three samples were taken from each site in every period, completing 24 samples. The sample design was carried out in a stratified way at random and three replicates were taken per site and then integrated to obtain a better representativity of the site. The material was fixed in situ and preserved in alcohol (70\%). The organisms were isolated under stereoscopic and optical microscope, and the counts were carried out considering the complete sample. The classification of Hydrachnidia families carried out by Cook $(1974,1980)$ and Rosso de Ferradás and Fernández (1995, 2001) were used for the taxonomical identification. The morphological characteristics were complemented with a recompilation of the existing information about families and genera of the obtained organisms (Cook, 1974; Rosso de Ferradás, 1975; 1984a, b; 1990, 2000; Rosso de Ferradás and Fernández, 1995, 2001; Dominguez and Fernández, 2009).

To describe the diversity of the Hydrachnidia community, the following variables were calculated: taxonomic richness: number of genera found in a defined sampling unit, abundance: numerical density (ind. $\mathrm{m}^{-2}$ ), and the Shannon - Wiener ( $\left.\mathrm{H}^{\prime}\right)$ specific diversity index. Kownacki's dominance index (1991) was used to calculate the intervals of number

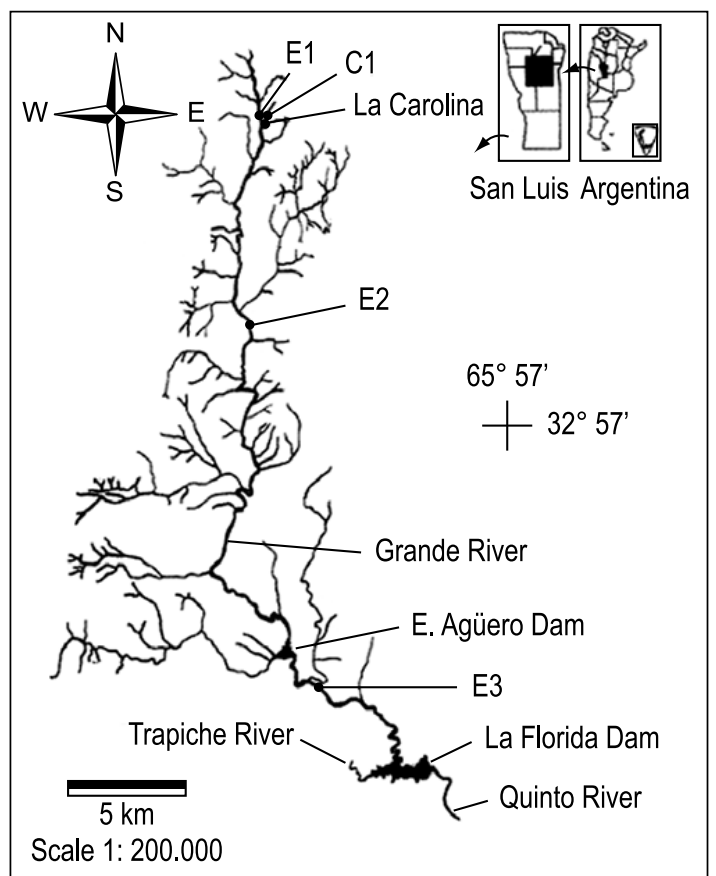

Figure 1. Sub-basin of the Grande River and sampling sites location.

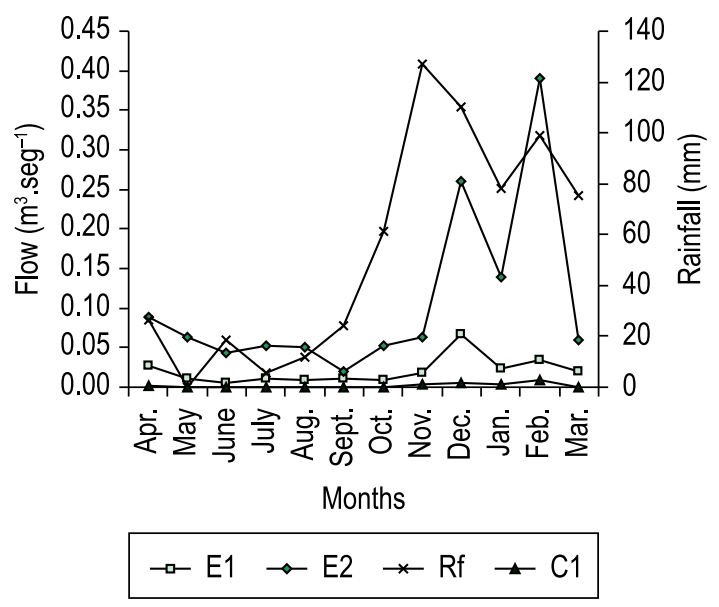

Figure 2. Flow curves in sites $\mathrm{C} 1, \mathrm{E} 1$ and $\mathrm{E} 2$ and hydrograph of rainfalls (Rf), in a full year, from April 1997 to March 1998.

Table 1. Geographical attributes of each sampling site in the Grande River.

\begin{tabular}{lcccc}
\hline & C1 & E1 & E2 & E3 \\
\hline Elevation $(m$ a.s.I. $)$ & 1,670 & 1,660 & 1,560 & 1,124 \\
Longitude $(\mathrm{km})$ & 1.5 & 2.35 & 9.77 & 24.24 \\
Stream order & $2^{\circ}$ & $2^{\circ}$ & $4^{\circ}$ & $6^{\circ}$ \\
\hline
\end{tabular}

abundance since it takes into account abundance as well as frequency, and it is calculated according to the following formula (Equation 1):

Ind. K. = (Q. 100. f $) / \Sigma \mathrm{Q}$ 
where $Q$ is the number of individuals of the examined genus in the series of examined samples; $\sum$ Q: the sum of the amount of individuals of all the genera; $f$ (frequency) $=n / N$; is the number of samples with representation of the studied genus; $\mathrm{N}$ is the number of samples in the series. According to the interval of number abundance presented by each genus, its participation is established within the community: A: dominant (between 10 and 100); B: subdominant (between 1 and 9,99); C: non dominant a (between 0,1 and 0,99 ); and $\mathrm{D}$ : non dominant $\mathrm{b}$ (between 0 and 0,099 ).

Non parametric statistics were used. The comparisons of the Hydrachnidia densities between the different sample sites were carried out using the Kruskal-Wallis statistics. The comparisons between the abundances of the samples obtained in the HW and LW periods in each site were carried out using the test for two related samples of Wilcoxon. The abiotic parameters of the different sites were compared using Kruskal-Wallis. The different hydraulic, physical and chemical variables were correlated with the abundance of the different Hydrachnidia genera using the Spearman's rank correlation coefficient. A dendrogram was drawn using the Bray-Curtis clusters analysis to measure similarity percentage and distance between the sites according to the Hydrachnidia densities. The statistical programs used were Statgraphics Plus version 5.1, Statistica version 5.0 and BioDiversity Professional version 2.0.

\section{Results}

Table 2 shows the values of the hydraulic, physical and chemical variables for the sampling sites in HW and LW. No significant differences were observed between the abiotic parameters and the different sample sites.

Sixteen Hydrachnidia genera were identified (Order Prostigmata) belonging to 10 families and 5 superfamilies. Table 3 shows generic richness values, diversity index and abundances of Hydrachnidia in each sampling site in both hydrological periods (HW and LW).

According to the spatial analysis, there were no significant differences in the Hydrachnidia abundances among the sample sites in HW and LW. In relation to the temporal analysis, the comparison of the abundances between HW and LW in each site, using Wilcoxon test, did not show any significant differences in E1 and E2. The same comparison could not be carried out for $\mathrm{C} 1$ and E3 because there were insufficient data for some pairs. When Hydrachnidia densities were averaged in both hydrological periods in each site, using the BrayCurtis ordination, a high degree of similarity was observed between the three non regulated sites (E1, E2, C1) whereas a lower degree of similarity was observed between these sites and E3 (Figure 3).

The genera with the highest densities, in descending order, were Hygrobates, Limnesia and Atractides. In relation to the distribution patterns of the different genera, Hygrobates appeared in every site, whereas Limnesia was absent in E3. The other genera appeared sporadically (Table 3 ). The distribution and abundance of these genera were reflected in the Kownacki's dominance index, which showed that Hygrobates and Limnesia were

Table 2. Hydraulic, physical and chemical variables in high water (HW) and low water (LW) hydrological periods, and mean of each site.

\begin{tabular}{|c|c|c|c|c|c|c|c|c|c|c|c|c|}
\hline \multirow[t]{2}{*}{ Variables } & \multicolumn{3}{|c|}{ C1 } & \multicolumn{3}{|c|}{ E1 } & \multicolumn{3}{|c|}{ E2 } & \multicolumn{3}{|c|}{ E3 } \\
\hline & $\mathrm{HW}$ & LW & Mean & HW & LW & Mean & LW & $A B$ & Mean & LW & $A B$ & Mean \\
\hline \multicolumn{13}{|l|}{ HYDRAULIC } \\
\hline Width (m) & 3.45 & 3.2 & 3.33 & 5.8 & 6 & 5.9 & 9.5 & 10.6 & 10.05 & 17.5 & 14 & 15.75 \\
\hline Mean depth (m) & 0.1 & 0.06 & 0.08 & 0.29 & 0.29 & 0.29 & 0.19 & 0.3 & 0.25 & 0.32 & 0.21 & 0.27 \\
\hline Velocity (m/seg.) & 0.03 & 0.03 & 0.03 & 0.08 & 0.07 & 0.08 & 0.15 & 0.05 & 0.1 & 0.3 & 0.36 & 0.33 \\
\hline $\begin{array}{l}\left.\text { Flow (m } \mathrm{m}^{3} / \mathrm{seg} .\right) \\
\text { PHYSICAL }\end{array}$ & 0.02 & 0.01 & 0.015 & 0.13 & 0.11 & 0.12 & 0.25 & 0.04 & 0.15 & 1.68 & 1.06 & 1.37 \\
\hline Water temperature $\left({ }^{\circ} \mathrm{C}\right)$ & 16 & 22.6 & 19.3 & 16.5 & 19.3 & 17.9 & 12 & 17.2 & 14.6 & 15 & 13 & 14 \\
\hline Turbidity (FTU) & 0 & 0 & 0 & 0 & 1 & 0.5 & 0 & 1 & 0.5 & 2 & 1 & 1.5 \\
\hline $\mathrm{pH}$ & 7 & 6.5 & 6.75 & 8.9 & 8 & 8.45 & 7.5 & 8.6 & 8.05 & 7.25 & 6.4 & 6.83 \\
\hline $\begin{array}{l}\text { Conductivity }\left(\mu \mathrm{S} . \mathrm{cm}^{-1}\right) \\
\text { CHEMICAL }\end{array}$ & 164 & 180 & 172 & 201 & 260 & 231 & 153 & 184 & 168.5 & 108 & 155 & 131.5 \\
\hline Alkalinity (mg.L-1 $\left.\mathrm{CO}_{3} \mathrm{Ca}\right)$ & 40 & 44 & 42 & 139 & 124 & 131.5 & 90 & 68 & 79 & 61 & 63 & 62 \\
\hline Total hardness $\left(\mathrm{mg}^{\mathrm{L} \mathrm{L}^{-1}} \mathrm{CO}_{3} \mathrm{Ca}\right)$ & 75 & 35 & 55 & 103 & 57 & 80 & 77 & 33 & 55 & 51 & 32 & 41.5 \\
\hline Hardness $\mathrm{Ca}\left(\mathrm{mg} \cdot \mathrm{L}^{-1} \mathrm{CO}_{3} \mathrm{Ca}\right)$ & 49 & 21 & 35 & 74 & 41 & 57.5 & 51 & 24 & 37.5 & 34 & 20 & 27 \\
\hline Hardness $\mathrm{Mg}\left(\mathrm{mg} \cdot \mathrm{L}^{-1} \mathrm{CO}_{3} \mathrm{Ca}\right)$ & 26 & 14 & 20 & 29 & 16 & 22.5 & 26 & 9 & 17.5 & 17 & 12 & 14.5 \\
\hline
\end{tabular}

Ref.: HW (high waters) and LW (low waters). 
"dominant", Atractides were "subdominant" and the rest were "non dominant" (Table 4 and Figure 4).

The high flows in E3 were due to the fact that the station was regulated by the Antonio Esteban Agüero dam, so they did not depend on the rainfalls but on the dam operation. In this site, Hygrobates presented a negative correlation with the flow and current velocity and only appeared in HW with low densities whereas Limnesia and Atractides were not observed. Other genera such as Sperchon, Torrenticola and Neoatractides, which were not observed in the pre-dam sites, appeared with positive correlations in relation to flow and current velocity (Table 5).

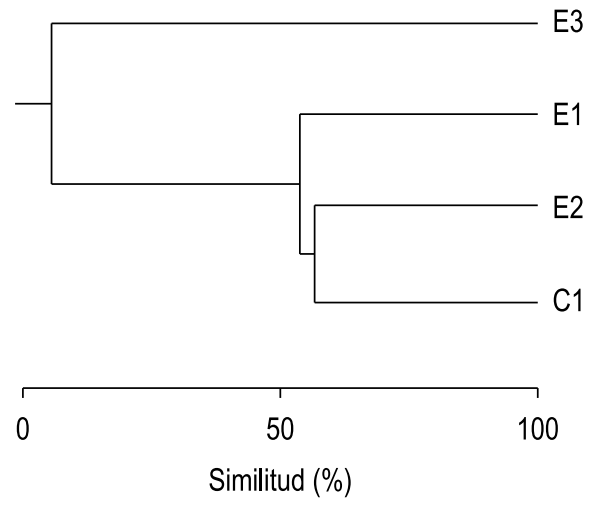

Figure 3. Dendrogram showing the similarity degree between the Hydrachnidia densities among the sites.

Table 3. Taxonomic classification, abundances, media, generic richness values and diversity index in each sampling site in the hydrological periods of HW and LW.

\begin{tabular}{|c|c|c|c|c|c|c|c|c|c|c|c|c|}
\hline \multirow[t]{3}{*}{ Classification } & \multicolumn{12}{|c|}{ Sampling of Sites } \\
\hline & \multicolumn{3}{|c|}{ C1 } & \multicolumn{3}{|c|}{ E1 } & \multicolumn{3}{|c|}{ E2 } & \multicolumn{3}{|c|}{ E3 } \\
\hline & HW & LW & Mean & HW & LW & Mean & HW & LW & Mean & HW & LW & Mean \\
\hline $\begin{array}{l}\text { HYDRACHNOIDEA } \\
\text { Hydrachnidae }\end{array}$ & & & & & & & & & & & & \\
\hline $\begin{array}{l}\text { Hydrachna } \\
\text { EYLAOIDEA } \\
\text { Limnocharidae }\end{array}$ & - & 18 & 9 & - & - & & - & - & & - & - & \\
\hline $\begin{array}{l}\text { Rhyncholimnochares } \\
\text { Eylaidae }\end{array}$ & - & - & & - & - & & 4 & 9 & 6,5 & 4 & - & 2 \\
\hline $\begin{array}{l}\text { Eylais } \\
\text { HYDRYPHANTOIDEA } \\
\text { Rhynchohydracharidae }\end{array}$ & - & - & & 6 & 19 & 12,5 & - & - & & - & - & \\
\hline $\begin{array}{l}\text { Clathrosperchon } \\
\text { LEBERTIOIDEA } \\
\text { Sperchontidae }\end{array}$ & - & - & & 11 & - & 5,5 & - & - & & - & - & \\
\hline $\begin{array}{l}\text { Sperchon } \\
\text { Torrenticolidae }\end{array}$ & - & - & & - & - & & - & - & & 11 & - & 5,5 \\
\hline Neoatractides & - & - & & - & - & & - & - & & - & 7 & 3,5 \\
\hline $\begin{array}{l}\text { Torrenticola } \\
\text { HYGROBATOIDEA } \\
\text { Limnesiidae }\end{array}$ & - & - & & - & - & & - & - & & 4 & - & 2 \\
\hline Limnesia & 7 & 37 & 22 & 102 & 72 & 87 & - & 15 & 7,5 & - & - & \\
\hline $\begin{array}{l}\text { Meramecia } \\
\text { Hygrobatidae }\end{array}$ & - & - & & - & - & & 30 & 9 & 19,5 & - & - & \\
\hline Hygrobates & - & 216 & 108 & 56 & 68 & 62 & 30 & 139 & 84,5 & 4 & - & 2 \\
\hline Atractides & - & - & & - & - & & 67 & 28 & 47,5 & - & - & \\
\hline Atractidella & - & - & & - & - & & 4 & - & 2 & 4 & - & 2 \\
\hline Hygrobatella & - & - & & - & - & & - & 9 & 4,5 & - & - & \\
\hline $\begin{array}{l}\text { Dodecabates } \\
\text { Unionicolidae }\end{array}$ & - & - & & - & 4 & 2 & - & 19 & 9,5 & - & - & \\
\hline $\begin{array}{l}\text { Koenikea } \\
\text { Aturidae }\end{array}$ & - & - & & 6 & - & 3 & - & - & & - & - & \\
\hline Kongsbergia & - & - & & - & - & & 7 & - & 3,5 & - & - & \\
\hline Whole Abundance & 7 & 271 & & 181 & 163 & & 142 & 228 & & 27 & 7 & \\
\hline Generic Riches & 1 & 3 & & 5 & 4 & & 6 & 7 & & 5 & 1 & \\
\hline Diversity of Index & - & 0,91 & & 1,56 & 1,54 & & 1,96 & 1,92 & & 2,16 & - & \\
\hline
\end{tabular}

Ref.: HW (high waters) and LW (low waters). 


\section{Discussion}

The different Hydrachnidia genera found in the different sampling sites of the Grande River correspond to separate groups from the systematic point of view, such as Hydrachna, Ryncholimnochares and Eylais which are considered more primitive groups phylogenetically; Sperchon which belong to intermediate evolution, and Kongsbergia which constitute more contemporary genera. However, most of the genera have common characteristics, which relate to organisms growing in a rheophilous medium. This fact has also been observed in several aquatic biotopes of the sierras pampeanas in the province of Córdoba (Rosso de Ferradás 1975, 1984 a, b, 1990, 1991, 2000; Rosso de Ferradás and Mattoni, 1999). The similarity between organisms and genera observed in the Grande River and

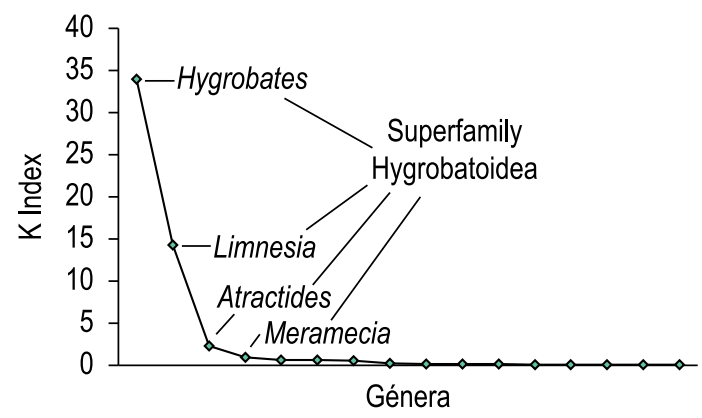

Figure 4. Intervals of numerical abundance of the different Hydrachnidia genera according to the Kownacki's dominance index, collected in the Grande River. the rivers in Córdoba was expected to be found since the hills in San Luis and in Córdoba belong to the Sierras Pampeanas system, exhibiting the same tectonic origin (Ceci and Cruz Coronado, 1981) and a similar biota (Medina et al., 1997; Vallania et al., 1998) with similar hydrological characteristics: increased flows during the rainfall season.

Hygrobates, Limnesia and Atractides presented the highest densities, and the first two genera were widely distributed in both hydrological periods (HW and LW). Although the causal analysis of these patterns is complex, three facts might explain these results. One possible cause is that in South America, the superfamily Hygrobatoidea presents the highest number of families, of which Hygrobatidae, Aturidae and Limnesiidae have the highest amount of genera and species. The family Hygrobatidae is predominantly rheophilous, with hyporheic shapes, and in Argentina, it is represented by eight genera whose distributions are related with the Andes Mountains and Sierras Pampeanas

Table 5. Correlation of the different Hydrachnidia genera in relation to flow and current velocity, according to the Spearmen rank correlation coefficient $(\mathrm{P}<0.05)$.

\begin{tabular}{lcc}
\hline $\begin{array}{c}\text { Hidrachnidia } \\
\text { genera }\end{array}$ & Flow & $\begin{array}{c}\text { Current } \\
\text { velocity }\end{array}$ \\
\hline $\begin{array}{l}\text { Sperchon } \\
\text { Neoatractides }\end{array}$ & $\mathrm{r}=0,9868 \mathrm{P}=0,9868 \mathrm{P}=0,013$ & $\mathrm{r}=0,9650 \mathrm{P}=0,035$ \\
Torrenticola & $\mathrm{r}=0,9868 \mathrm{P}=0,013$ & $\mathrm{r}=0,9650 \mathrm{P}=0,0650 \mathrm{P}=0,035$ \\
Hygrobates & $\mathrm{r}=-0,9929 \mathrm{P}=0,007$ & $\mathrm{r}=-0,9767 \mathrm{P}=0,023$ \\
\hline
\end{tabular}

Table 4. Intervals of numerical abundance calculated by Kownacki's dominance index of the Hydrachnidia genera collected in the Grande River.

\begin{tabular}{|c|c|c|c|c|}
\hline Genera & Abundance & Frequency & Index K & Intervals \\
\hline Hydrachna & 18 & 0,125 & 0,22 & $C$ \\
\hline Rhyncholimnochares & 17 & 0,375 & 0,62 & C \\
\hline Eylais & 25 & 0,25 & 0,61 & C \\
\hline Clathrosperchon & 11 & 0,125 & 0,13 & C \\
\hline Sperchon & 11 & 0,125 & 0,13 & C \\
\hline Neoatractides & 7 & 0,125 & 0,08 & D \\
\hline Torrenticola & 4 & 0,125 & 0,04 & D \\
\hline Limnesia & 233 & 0,625 & 14,25 & A \\
\hline Meramecia & 39 & 0,25 & 0,95 & C \\
\hline Hygrobates & 463 & 0,75 & 33,98 & A \\
\hline Atractides & 95 & 0,25 & 2,32 & B \\
\hline Atractidella & 8 & 0,25 & 0,19 & C \\
\hline Hygrobatella & 9 & 0,125 & 0,11 & C \\
\hline Dodecabates & 23 & 0,25 & 0,56 & C \\
\hline Koenikea & 6 & 0,125 & 0,07 & D \\
\hline Kongsbergia & 7 & 0,125 & 0,08 & D \\
\hline
\end{tabular}

Ref.: A: dominant (10-100); B: subdominant (1-9,99); C: non dominant a (0,1-0,99); and D: non dominant b $(0-0,099)$. 
(Cook, 1980). The most representative genera corresponding to this family are Hygrobates and Atractides, both of which are widely distributed in Argentina, with several species found in Sierras Pampeanas in the province of Córdoba (Rosso de Ferradás and Mattoni, 1999). The genus Limnesia, from the Family Limnesiidae, includes eurichora species found in different environments in our country (Cook, 1980). Several species have been found in the aquatic habitat of Córdoba.

Another cause might be related to the parasitehost and predator-prey interactions exhibited by the Hydrachnidia. The benthonic macroinvertebrates fauna of the Grande River (Vallania, 2003; Vallania and Corigliano, 2007; Medina and Vallania, 2001; Medina and Paggi, 2004; Medina et al., 2008) show a great abundance of certain groups such as Chironomidae larvae (Diptera), larvae of Caenis sp., Baetis sp and Tricorythodes sp. (Ephemeroptera), Helicopsyche sp. (Trichoptera), larvae of Elmidae (Coleoptera), Chaetogaster sp. and Nais sp. (Oligochaeta). Most of these organisms are potential hosts and preys of the mentioned Hydrachnidia families. The hosts of Limnesiidae are diptera larvae (Ceratopogonidae, Chironomidae and Tipulidae), whereas their preys are Chironomidae larvae, other soft Hydrachnidia, microcrustaceans (Cladocera and Copepoda), Odonata larvae, Plecoptera and fish eggs. As regards Hygrobatidae, their hosts are diptera larvae (Chironomidae, Chaboridae and Tipulidae) and their preys are small crustaceans, larvae of Culicidae and Chironomidae and fish eggs. Finally, the above mentioned families are considered to be "generalists" due to prey variety (Proctor and Pritchard, 1989), which might permit a wider range of "ecological niches" of Hydrachnidia species belonging to those families, thus extending survival possibilities.

In a previous study carried out in sites E2 and E3, a significant decrease in the densities and changes in the composition of the macroinvertebrates communities were observed which were explained by the modifications in the hydraulic and physicochemical parameters caused by the dam regulation (Vallania and Corigliano, 2007). However, in the present work, the decrease in the Hydrachnidia densities in E3 in relation to E2 (Figure 3) and the changes in their composition could not be explained by the direct influence of the abiotic parameters despite the correlations found in some genera in relation to flow and current velocity. In fact, any change in the benthonic macroinvertebrates might affect these arachnids due to parasitism and predation. In this sense, such abiotic interactions might exert more significant influence than the proposed abiotic parameters (Monkolski et al., 2005) on the densities decrease and the changes in the composition of the Hydrachnidia in E3.

\section{Acknowledgements}

The authors wish to thank the members of Project 9401 (UNSL) and other researchers who also contributed to this work.

\section{References}

CECI, JH. and CRUZ CORONADO, MD. 1981. Recursos hídricos subterráneos. In Geología de la Provincia de San Luis, VII Congreso Geológico Argentino Rel. p. 301-322.

COOK, D. 1974. Water mite genera and subgenera. Memoirs of the American Entomológical Institute, no. 2, p. $1-860$

COOK, D. 1980. Studies on neotropical water mite. Memoirs of the American Entomological Institute, no. 31, p. 1-645.

DOMINGUEZ, E. and FERNÁNDEZ, H. 2009. Macroinvertebrados bentónicos sudamericanos. Sistemática y biología. Tucumán, Argentina: Fundación Miguel Lillo. p. 656.

EVANS, EO. 1992. Clasification of the Acari: principles of acarology. cap. 12, p. 377-475.

FERNÁNDEZ, H. and FERRADÁS, ROSSO 2008. Hidrachnidia. Biodiversidad de Artrópodos Argentinos, vol. 2, p. 117-127.

MEDINA, AI. and PAGGI, AC. 2004. Composición y abundancia de Chironomidae (Diptera) en un río serrano de zona semiárida (San Luis, Argentina). Revista Sociedad. Entomologica Argentina, vol. 63, no. 3-4, p. 107-118.

MEDINA, AI. and VALLANIA, A. 2001. Ephemeroptera: Abundance and Distribution in Regulated Streams (San Luis, Argentina). In DOMÍNGUEZ, E., ed. Trends in Research in Ephemeroptera \& Plecoptera. New York: Kluwer Academic/Plenium Publishers. p. 143-148.

MEDINA, AI., SCHEIBLER, EE. and PAGGI, AC. 2008. Distribución de Chironomidae (Diptera) en dos sistemas fluviales ritrónicos (Andino-serranos) de Argentina. Revista Sociedad Entomologica Argentina, vol. 67, no. 1-2, p. 69-79.

MEDINA, AI., VALLANIA, A., TRIPOLE, S. and GARELIS, P. 1997. Estructura y composición del zoobentos de ríos serranos (San Luis). Ecología Austral, no. 7, p. 28-34.

MONKOLSKI, A., TAKEDA, AM. and MARIA DE MELO, S. 2005. Fauna structure of water mites associated with Eichhornia azurea in two lakes of the upper Paraná floodplain, Mato Grosso do Sul State, 
Brazil. Acta Scientiarum Biological Sciences, vol. 27, no. 4, p. 329-337.

PROCTOR, H. and PRITCHARD, G. 1989. Neglected predators: water mites (Acari: Parasitengona: Hydrachnellae) in freshwater communities. Journal North American Benthological Society, vol. 8, no. 1, p. 100-111.

ROSSO DE FERRADÁS, B. 1975. Acaros Acuáticos (Acari, Hydrachnellae) de Lagos de Embalse y Cuencas Relacionadas de la Provincia de Córdoba, Republica Argentina. Physis Secc. B., vol. 34, no. 88, p. 27-35.

ROSSO DE FERRADÁS, B. 1984 a. Hidracáridos de la provincia de Buenos Aires (Argentina). I. Arrenuridae (Acari, Hydrachnellae) del delta del Paraná. Physis, vol. 42, no. 103 , p. 77-85.

ROSSO DE FERRADÁS, B. 1984b. Hidracáridos de Copina (Departamento Punilla, Córdoba, Argentina) Acari, Hydrachnidia. Comunicaciones del MACN”B. Rivadavia. Hidrobiología, vol. 2, no. 11, p. $124-140$.

ROSSO DE FERRADÁS, B. 1987. Ácaros acuáticos patagónicos (Acari, Hydrachnidia). I. Embalse Ezequiel Ramos Mexía (Argentina, Neuquén). Studies on Neotropical Fauna and Environment, vol. 22, no. 1, p. 25-41.

ROSSO DE FERRADÁS, B. 1990. Acaros reófilos de las sierras de Córdoba (República Argentina) (Acari, Hydrachnidia) I; Studies on Neotropical Fauna and Enviroment, vol. 25, no. 4, p. 185-197.

ROSSO DE FERRADÁS, B. 1991. Acaros reófilos de las sierras de Córdoba II. Género Corticacarus (Acari, Hydrachnidia, Hygrobatidae). Revista Sociedad Entomologica Argentina, vol. 49, no. 1-4, p. 121-130

ROSSO DE FERRADÁS, B. 2000. Acaros reófilos (Acari: Hydrachnidia) de las sierras de Córdoba IV. Revista Sociedad Entomologica Argentina, vol. 59, no. 1-4, p. 25-40.

ROSSO DE FERRADÁS, B. and FERNÁNDEZ, HR. 1995. Acari Hydrachnidia. In LOPRETTO, EC. and
TALL, G., ed. Ecosistemas de aguas continentales. La Plata: Ediciones Sur. p. 819-853.

ROSSO DE FERRADÁS, B. and FERNÁNDEZ, HR. 2001. Acari. Guía para la Determinación de los Artrópodos Bentónicos Sudamericanos, no. 11, p. 237-256.

ROSSO DE FERRADÁS, B. and FERNÁNDEZ, HR. 2005. Elenco y Biogeografía de los Ácaros Acuáticos (Acari, Parasitengona, Hydrachnidia) de Sudamérica. Graellisia, vol. 62, no. 2, p. 181-224.

ROSSO DE FERRADÁS, B. and FERNÁNDEZ, HR. 2009. Acari, Parasitengona, Hydrachnidia. In DOMÍNGUEZ, E. and FERNÁNDEZ, HR., ed. Macroinvertebrados Bentónicos Sudamericanos. Sistemática Biológica. Tucumán: Fundación Miguel Lillo. p. 497-551.

ROSSO DE FERRADÁS, B. and MATTONI, CI. 1999. Acaros reófilos (Acari: Hydrachnidia) de las sierras de Córdoba (Argentina) III. Revista Sociedad Entomologica Argentina, vol. 58, no. 3-4, p. 109-127.

STRAHLER, AN. 1957. Quantitative analysis of Watershed Morphology. Trans. Am. Geoghys. Union, no. 38, p. 913-920.

VALLANIA, EA. 2003. Cambios inmediatos en la comunidad de macroinvertebrados a la regulación en un arroyo serrano. Universidad Nacional del Litoral. [Tesis de Maestría].

VALLANIA, EA. and CORIGLIANO M. 2007. The effect of regulation caused by a dam on the distribution of the functional feeding groups of the benthos in the sub basin of the Grande river (San Luis, Argentina). Environmental Monitoring and Assessment, no. 124, p. 201-209.

VALLANIA, EA., MEDINA, I. and SOSA, ME. 1998. Estructura de la comunidad de Trichoptera en un arroyo regulado (San Luis - Argentina). Revista Sociedad Entomologica Argentina, vol. 57, no. 1-4, p. 7-11.

Received: 07 December 2009

Accepted: 25 November 2010 